\title{
The Asian decapod Hemigrapsus penicillatus (de Haan, 1835) (Grapsidae, Decapoda) introduced in European waters: status quo and future perspective
}

\author{
S. Gollasch \\ Institut für Meereskunde, Düsternbrooker Weg 20, 24105 Kiel, Germany
}

\begin{abstract}
The Asian decapod Hemigrapsus penicillatus (de Haan, 1835) was first recorded in European waters in 1994. The first specimens were collected in the estuary of Charente Maritime on the west coast of France close to La Rochelle. The current range in Europe covers Spanish shallow water habitats of the Bay of Biscay to areas north of La Rochelle (France). Densities of up to 20 specimens per square metre occur. This species has a high temperature and salinity tolerance and will expand its distribution in European waters. It is not clear whether this crab was introduced by shipping in ballast water or as a fouling organism. Based on a study of ship hull fouling in German dry docks this account provictes evidence that hull fouling is a likely vector for the introduction of this crab. In August 1993, six juvenile specimens of $H$. penicillatus were removed from the hull of a car-carrier. After its journey from Japan into European waters this vessel docked in the port of Bremerhaven (Germany) for a routine inspection and coating with antifouling paint.
\end{abstract}

\section{INTRODUCTION}

More than 100 non-indigenous species occur in European waters and many of these document the introduction of species by anthropogenic support. Shipping has been indicated as a major vector of introduction. Two principle means that enable effective transport of exotic species with ships are known: ballast water and hull fouling (Carlton \& Geller, 1993). The first non-indigenous species which is believed to have been introduced with ballast water into the North Sea, the diatom Biddulphia (Odontella) sinensis, bloomed in 1903 (Ostenfeld, 1908). Ballasting ships with water at sea is general practice today. The technique was developed in the late nineteenth century as a more efficient way than any previous means using stones, sand or any other solid ballast material. The volumes of ballast water transported are considerable. Shortening sea journeys is likely to aid in more successful species introduction beyond their natural ranges.

Besides ballast water, hull fouling comes more and more into focus as a vector for species transportation and was considered to be the principal vector for species introduction (Hentschel, 1923; Pyefinch, 1950; Southward \& Crisp, 1963; Gollasch \& Riemann-Zürneck, 1996). The use of antifouling systems has reduced the number of specimens transferred, but shipping activity has increased drastically, thereby enabling larger volumes of ballast water and higher numbers of organisms to be transferred than 
ever before. As a consequence, probabilities of further species successfully establishing themselves in new habitats have also increased. It was generally believed that the use of organotin antifouling paints greatly reduced fouling intensity. However, fouling still remains an important vector of species transmission. Hemigrapsus penicillatus was found in ship hull samples taken during a German shipping study, indicating hull fouling as the possible introducing vector of the species to European waters. This is the first record of this species from a ship's hull. Due to the high temperature and salinity tolerance of the species, further spread in European waters is expected.

\section{MATERIALS AND METHODS}

During a German shipping study the ballast water, tank sediments and ship hulls of ocean-going vessels were sampled. During a period of 4 years 131 ship hulls of vessels newly docked were sampled in the German shipyards of Hamburg and Bremerhaven (Gollasch 1996; Lenz et al., in press). Among them was the car-carrier SPICA, built in 1981, which is able to transport a maximum of 5900 cars. The vessel is approx. 14000 dead weight tonnes (DWT), nearly $190 \mathrm{~m}$ long and $32.2 \mathrm{~m}$ wide. The maximum summer draught is $8.82 \mathrm{~m}$. The estimated surface covered by water is $6500 \mathrm{~m}^{2}$. Its average cruising speed of 17 knots enables this vessel to provide a regular service, calling at European ports every 3 months. On its way from Asia to Europe the ship visits the ports of Tokyo, Osaka, Kobe (Japan), and Pusan (Korea), crosses the Indian Ocean and passes through the Suez Canal before docking at the port of Bremerhaven.

Samples were collected on 14 August 1993, $1 \mathrm{~h}$ after the ship had been docked in Bremerhaven. The sampling points on the vessel's surface were randomly chosen; three samples of 10 by $10 \mathrm{~cm}$ were scraped off from the fouled surface near the bow. The thickness of the fouling covering the hull at the sampling sites varied from 2 to $7 \mathrm{~cm}$. The species found were preserved with $70 \%$ ethanol.

\section{RESULTS}

A total of six living specimens of $H$. penicillatus (Fig. 1), two males and four females, were identified from the three hull fouling samples. The specimens were obtained in two of the three samples removed from the bow area of the ship. All specimens were in a good condition despite the fact that the ship was in the dry-dock for about $1 \mathrm{~h}$ while also exposed to brackish water conditions (salinity at the dock site usually between $12 \%$ and $24 \%$ ).

None of the female specimens were ovigerous. The width of the carapace ranged from 8 to $11 \mathrm{~mm}$. All species were found in empty shells of the barnacle Balanus amphitrite or $B$. perfortatus and on sheltered regions (with respect to currents) of the hull shown by an overgrowth of mussels (Mytilus edulis) and oysters (Crassostrea gigas). The fouling community of macrozoobenthos species covered nearly $10 \%$ of the permanently submerged ship surface (about $650 \mathrm{~m}^{2}$ ). At the sampling sites the total hull coverage with fouling ranged from $60 \%$ to $90 \%$.

The German shipping study revealed in total 150 species non-indigenous to the North Sea and the Baltic, found either in ballast water, tank sediments or associated 


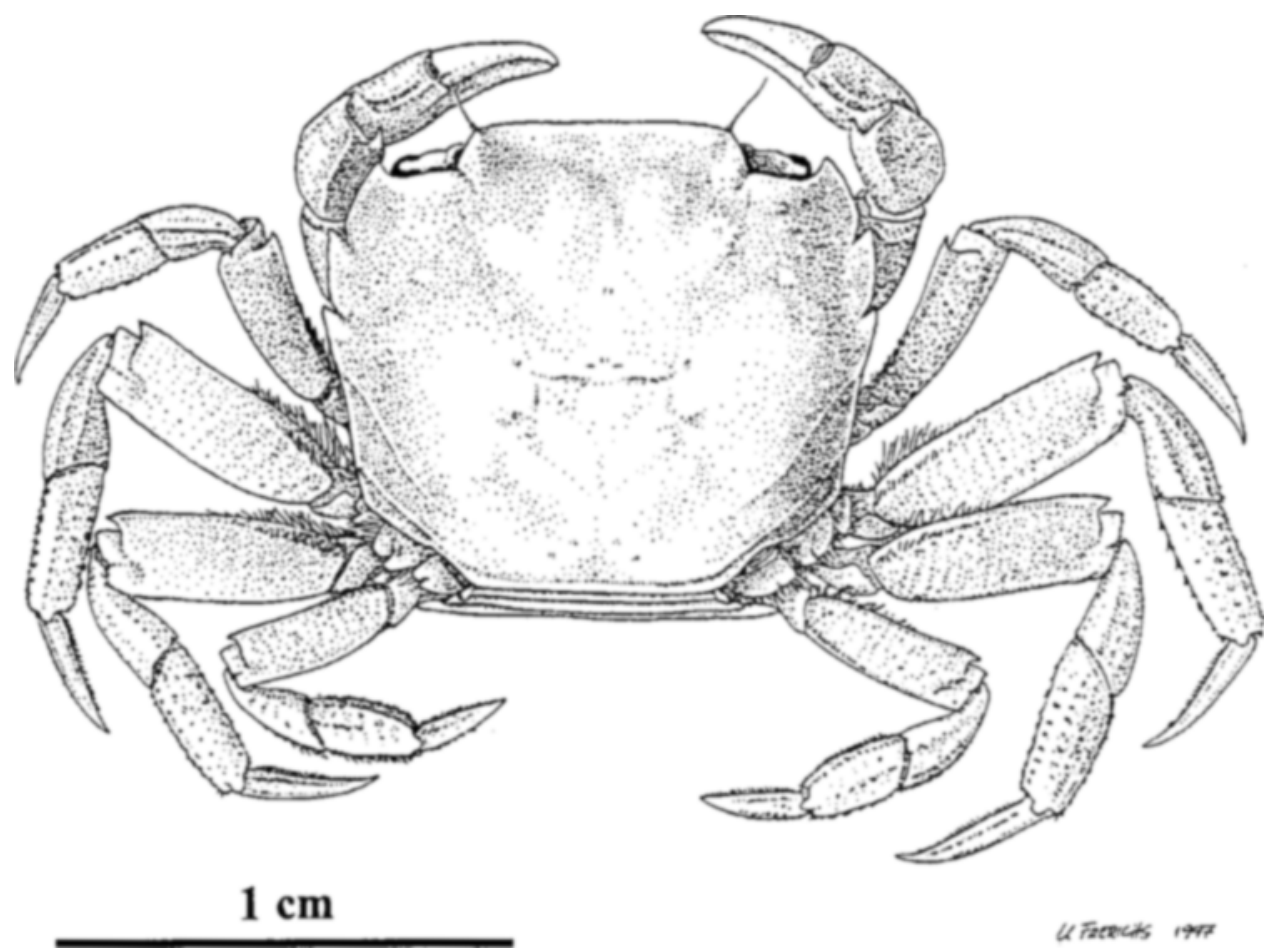

Fig. 1. Hemigrapsus penicillatus from the French coast. Drawn by Ursuld Frerichs (Zoologisches Institut und Zoologisches Museum, Hamburg)

with hull fouling. Crustacea were the most abundant taxonomic group, followed by Mollusca. Eight decapod species were found, including three grapsid crabs: Brachynotus sexdentatus, H. penicillatus and Pachygrapsus gracilis in the hull samples (Gollasch, 1996; Lenz et al., in preparation).

This is the first direct observation of long-range transmission and survival of $H$. penicillatus on a ship hull of a fast ocean-going vessel.

\section{DISCUSSION}

Several decapods have been introduced by means of shipping to new localities around the world. Examples are the green crab Carcinus maenas (native to Europe) (Alcock, 1899; Pollard \& Hutchings, 1990; McDermott, 1991; Hedgpeth, 1993; Jackson, 1993), the Chinese mitten crab Eriocheir sinensis, established in Europe since 1912 (Peters et al., 1936; Eno et al., 1997), and occasional findings of the blue crab Callinectes sapidus (den Hartog \& Holthuis, 1951; Kühl, 1965; Christiansen, 1969; Holthuis, 1969) as well as other decapods, e.g. Processa aequimana (Walford \& Wicklund, 1973) and Rithropanopeus harrisii (Christiansen, 1969; Walford \& Wicklund, 1973; Eno et al. 1997) which are believed to have been introduced by ships (Carlton, 1985). 
After the first European record of a 1-year-old specimen of $H$. penicillatus in 1994, found in the area of Charente Maritime close to La Rochelle, Noël (1997) and Noël et al. (1997) believed that the introduction of the species must have taken place in 1993.

\section{Vectors of introduction}

In 1993 the car-carrier under study passed the French coast unintentionally transporting probably several hundreds of specimens of $H$. penicillatus. It is likely that this particular vessel could have been a vector for the introduction of this species into French waters. It is assumed that specimens dropped of the bottom of the ship in sufficient numbers to generate a new population. There may be different reasons for the specimens being washed away from the ship's hull: mechanical reasons (scratched away by floating objects such as wood or plastic) or the lack of food available on the ship's hull, which made migration to another habitat necessary.

Although the hull of only one of 131 sampled vessels contained $H$. penicillatus, the finding of six specimens from $0.3 \mathrm{~m}^{2}$ of hull surface is significant. The behaviour of $H$. penicillatus living beneath stones and rocks in its native habitat suggested that homing in empty shells of barnacles was likely. A Japanese investigation showed that $H$. penicillatus was frequently found even in beverage cans (Ogura \& Kishi, 1985). The behaviour of using sheltered habitats to protect itself against predators (Kurihara \& Okamoto, 1987; Okamoto \& Kurihara, 1987) and probably strong water currents offered, in addition, the possibility of becoming widely distributed on the hull of ships or other floating objects. There is a need to study the conditions with regard to currents, surface structure, microturbulence and drag forces under which crab species would be able to hold on to be successfully transported. Such data would be useful to evaluate the likelihood for success of transmission and enable us to determine criteria for hull surface management to reduce the survival of unwanted species.

Another potential introducing vector could have been the transport as larvae in the ballast water of ships - which has not (yet) been confirmed by sampling ballast water or sediments in ballast tanks during several shipping studies. It is assumed that the discharge of ballast water has caused the majority of species introductions worldwide (Carlton, 1985, 1991; Gollasch, 1996). During the 6-week voyage from Japan to Western Europe, the larval development of $H$. penicillatus could have been completed in the ballast tank. According to Ogura \& Kishi (1985) the zoeal stage lasts 25 days at $20-22{ }^{\circ} \mathrm{C}$ or 16 days at $24-28^{\circ} \mathrm{C}$ followed by a 6 -day megalopa stage. However, it should be taken into account that the survival rate of specimens during interoceanic voyages is negatively influenced by potential mechanical damage during the pumping process involved in uptake and release of ballast water. Additionally, it is known that an increasing period of time in the ballast tank decreases the survival rate of zooplankton species (Gollasch et al., in press).

Imports of living specimens for aquaculture purposes are an additional well-known vector of species introductions. The area of the Charente estuary where $H$. penicillatus was first recorded (Noël; 1997; Noël et al., 1997), is one of the most important aquaculture sites for oyster culturing in the world. Associated with imports of living oysters, more than 100 non-target species have been transported unintentionally, ranging from 
protozoans, phytoplankton, and macroalgae to invertebrates (Bonnot, 1935; Kincaid, 1949; Korringa, 1951; Haigler, 1969; Miller, 1969; Kornicker, 1975; Edwards, 1976; Andrews, 1980; Farnham, 1980; Christiansen \& Thomsen, 1981; Carlton, 1991; Minchin et al., 1993; Reise, 1993; Minchin 1996). However, no living adult oysters or oyster seeds have been imported to the Charente estuary over the last few decades. It is believed that if this species was introduced with the most recent oyster imports in the $1970 \mathrm{~s}$ (Goulletquer, 1997, personal communication), it would not have been overlooked for such a long period of time. Therefore, this vector can be excluded.

Nevertheless, it is believed that $H$. penicillatus was introduced by fouling of ship hulls. During the German shipping study, specimens of $H$. penicillatus were determined in samples taken at exactly the time the estimated introduction of the species into European waters took place; the lack of introducing vectors e.g., imports of oysters, makes an introduction via hull fouling most probable. Australian results showed, in the same way as the results of the German shipping study, that the highest number of non-indigenous species carried by ships was not found in ballast water but in ship hull fouling (Gollasch, 1996; Hewitt, 1998, personal communication). Surprisingly, even a previously unknown species (Cryptostylochus hullensis, Plathelminthes) was found on the ship's hull during the German shipping study (Faubel \& Gollasch, 1997).

\section{Impacts}

Williams (1996) and Simberloff et al. (1997) concluded that all non-indigenous species are potentially harmful. Possible impacts of the introduced crab are not yet known. Non-indigenous species can have several types of impact (direct, indirect and synergistic) on native species. The feeding of Hemigrapsus spp. on snails such as Littorina spp. (Boulding \& Van Alstyne, 1993; Yamada \& Boulding, 1996) and egg capsules of the gastropod Nucella spp. (Rawlings, 1990), on algae (Enteromorpha spp. and diatoms) and detritus under laboratory conditions (Okamoto \& Kurihara, 1989) can lead to competition with native species, especially, during mass occurrences. It is believed that any species with a density of up to 20 individuals per meter square must have an effect on trophic relationships on the shore it has invaded. If there is no predation on other species, competition for space and possibly food could be a negative impact. Burrowing activities of decapod crabs could damage riverbanks or dikes, as happened in German waters during a mass occurrence of the introduced Eriocheir sinensis in the 1930s (Panning \& Peters, 1932, 1933; Peters et al., 1936), but in the native area of the species $H$. penicillatus is not known to burrow into sediments. Further research in this field should focus on the competition by other macro-invertebrates such as Carcinus maenas and in estuaries by the Chinese mitten crab Eriocheir sinensis.

\section{Spread}

The native habitat of $H$. penicillatus ranges from northern Japan (cold-temperate climate) to China (warm-temperate climate) (Pillay \& Ono, 1978; Dai \& Yang, 1991; Noël et al., 1997; Türkay 1996, personal communication). Its native range of habitats includes muddy as well as rocky shores. The preferred habitat is under stones in the mid-littoral 
zone. Both estuaries and port areas are colonized (Okamoto \& Kurihara, 1987). Up to six broods can be produced during a breeding season within its native range (Pillay \& Ono, 1978).

Three years after the first record in Europe and 4 years after its introduction, $H$. penicillatus now occurrs locally in densities of up to 20 specimens per square metre (Noël et al., 1997). Because of the matching climates in the native distribution area of $H$. penicillatus and European waters and its high salinity tolerance (Kikuchi \& Matsumasa, 1991), it is assumed that this species will spread further along the European coasts (Noël et al., 1997). The combination of temperature tolerance down to freezing point, tolerance of lower salinities and the high rate of reproduction explains the development of numerous specimens in a short period of time and a high rate of spread, as shown along the Atlantic coasts of France and Spain. Due to matching climate and abiotic conditions, it is predicted that $H$. penicillatus is enabled to colonize a wide range of habitats along the North Sea and western Baltic shores.

Acknowledgements. Grateful thanks are expressed to Dr. M. Türkay, who kindly confirmed the species determination as well as to the shipyard and shipping company for their co-operation. M. Dammer commendably helped during sampling in the dockyard. Financial support was given by the Umweltbundesamt, Berlin. Dr. Dan Minchin (Fisheries Research Centre, Dublin, Ireland) provided invaluable advice and comments on the manuscript.

\section{LITERATURE CITED}

Alcock, A., 1899. Materials for a carcinological fauna of India. No. 4. The Brachyura Cyclometopa. Part II. A revision of the Cyclometopa with an account of the families Portunidae, Cancridae and Corystidae. J. Asiatic Soc. Bengal, 1-104

Andrews, J. D., 1980. A review of introductions of exotic oysters and biological planning for new importations. Mar. Fish. Rev. 42, 1-11.

Bonnot, P., 1935. A recent introduction of exotic species of molluscs into California waters from Japan. Nautilus 49, 1-2.

Boulding, E. G. \& Van Alstyne, K. L., 1993. Mechanisms of differential survival and growth of two species of Littorina on wave-exposed and on protected shores. J. Exp. Mar. Biol. Ecol. 169, 139166.

Carlton, J. T., 1985. Transoceanic and interoceanic dispersal of coastal marine organisms: the biology of ballast water. Oceanogr. Mar. Biol. Annu. Rev. 23, 313-371.

Carlton, J. T., 1991. Overview of the issues concerning marine species introductions and transfers. In: Proceedings of the conference and workshop. Introductions and transfers of marine species. Achieving a balance between economic development and resource protection. Conference papers. Ed. by R. DeVoe. Bd. Session IV, S. C. Sea Grant Consortium, USA, 65-67.

Carlton, J. T. \& Geller, J. B., 1993. Ecological roulette: the global transport of non-indigenous marine organisms. Science 261,78-82.

Christiansen, J. \& Thomsen, J. C., 1981. Styela clava Herdman, 1882, a species new to the Danish fauna (Tunicata, Ascidiacea). Stennstrupia 7, 15-24.

Christiansen, M. E., 1969. Crustacea Decapoda Brachyura. Marine invertebrates of Scandinavia. No. 2. Universitetsforlaget, Oslo, $143 \mathrm{pp}$.

Dai, A. Y. \& Yang, S. L., 1991. Crabs of the China Seas. Ocean Press (Beijing) and Springer (Berlin Heidelberg New York), $608 \mathrm{pp}$.

den Hartog, C. \& Holthuis, L. B., 1951. De Noord-Americaanse "Blue Crab" in Nederland. Levende Nat. 54, 121-125.

Edwards, C., 1976. A study in erratic distribution: the occurrence of the medusa Gonionemus in relation to the distribution of oysters. Adv. Mar. Biol. 14, 251-284. 
Eno, C. N., Clark, R. A. \& Sanderson W. G. (eds), 1997. Non-native marine species in British waters: a review and directory. Joint Nature Conservation Committee, Petersborough, 152 pp.

Farnham, W. F., 1980. Studies on aliens in the marine tlora of southern England. In: The shore environment, vol 2. Ed. by J. H. Price, D. E. G. Irvine \& W. F. Farnham. Academic Press, London, $875-914$.

Faubel, A. \& Gollasch, S., 1997. Cryplostylochus hullensis n. sp. (Polycladida, Acotylea, Plathelminthes): a possible case of trans-oceanic dispersal on a ship's hull. Helgoländer Meeresunters. 50, 533-537.

Gollasch, S., 1996. Untersuchungen des Arteintrages durch den internationalen Schiffsverkehr unter besonderer Berücksichtigung nichtheimischer Arten. Dissertation, Universität Hamburg, Verlag Dr. Kovac, Hamburg, 314 pp.

Gollasch, S. \& Riemann-Zürneck, K., 1996. Transoceanic dispersal of benthic macrofauna: Haliplanella luciae (Verrill, 1898) (Anthozoa, Actinaria) found on a ship's hull in a shipyard dock in Hamburg Harbour, Germany. Helgoländer Meeresunters. 50, 253-258.

Gollasch, S. Lenz, J., Dammer, M. \& Andres, H.-J.: Survival of tropical ballast water organisms during a cruise from the Indian Ocean to the North Sea (in press)

Haigler, S. A., 1969. Boring mechanism of Polydora websteri inhabiting Crassostrea virginica. Am. Zool. 9, 821-828.

Hedgpeth, J. W., 1993. Foreign invaders. Science 261, 34-35.

Hentschel, E., 1923. Der Bewuchs an Seeschiffen. Int. Rev. Ges. Hydrobiol. 11, $238-264$.

Holthuis, L. B., 1969. Enkelen interessante Nederlandse Crustacea. Bijdragen Faunistiek Nederland $1,34-48$.

Jackson, L. F., 1993. Harmful marine organisms in ballast water: possible implications for South Africa. Sea Fish. Res. Inst., Cape Town, South Africa, 7 pp.

Kikuchi, S. \& Matsumasa, M., 1991. Differentiation of the gill epithelia and the habitats in crabs: an ultrastructural study of the distribution of the osmoregulating and non-osmoregulating epithelia. Zool. Sci. 8, 1162.

Kincaid, T., 1949. Note on introduced molluscs. Molluscs found in boxes of seed oysters from Japan identified by Dr. Myra Keen. Minutes of the Conchological Club of Southern California, 88, 1.

Kornicker, L. S., 1975. Spread of Ostracodes to exotic environs on transplanted oysters. Bull. Am. Paleontol. 65, 129-139.

Korringa, P., 1951. The shell of Ostrea edulis as a habitat. Arch. Neerl. Zool. 10, 32-152.

Kühl, H., 1965. Fang einer Blaukrabbe, Callinectes sapidus Rathbun (Crustacea, Portunidae) in der Elbmündung. Arch. Fischereiwiss. 15, 225-227.

Kurihara, Y. \& Okamoto, K., 1987. Cannibalism in a grabsid crab, Hemigrapsus penicillatus. Mar. Ecol. Prog. Ser. 41, 123-127.

Lenz, J., Andres, H.-J., Gollasch, S. \& Dammer, M. Einschleppung fremder Organismen in die Nord- und Ostsee: Untersuchungen zum ökologischen Gefahrenpotential durch den Schiffsverkehr. Umweltbundesamt, Texte. In press [in German].

McDermott, J. J., 1991. A breeding population of the Western Pacific crab Hemigrapsus sanguineus (Crustacea: Decapoda: Grapsidae) established on the Atlantic Coast of North America. Biol. Bull. (Woods Hole) 181, 195-198.

Miller, R. L., 1969. Ascophyllum nodosum: a source of exotic invertebrates introduced into west coast near-shore marine waters. Veliger 12, 230-231.

Minchin, D., 1996. Management of the introduction and transfer of marine molluscs. Aquat. Cons.: Mar. Freshw. Ecosyst. 6, 229-244.

Minchin, D., Duggan, C. B., Holmes, J. M. C. \& Neiland, S., 1993. Introductions of exotic species associated with Pacific oyster transfers from France to Ireland. International Council for the Exploration of the Sea, Working Group on Introductions and Transfers of Marine Organisms, Aberdeen, Scotland, 1-7.

Noël, P. Y., 1997. Presentation on the introduction of the Asian shore crab Hemigrapsus penicillatus. Abstract presented at the Meeting of the International Council for the Exploration of the Sea. Working Group on Introductions and Transfers of Marine Organisms, La Tremblade, France, 1. 
Noël, P., Tardy, E. \& D'Udekem D'Acoz, C., 1997. Will the crab Hemigrapsus penicillatus invade the coasts of Europe? C.R. Acad. Sci. Paris, Sciences de la vie/Life Sci. 320, 741-745.

Ogura, M. \& Kishi, Y., 1985. Reproductive period and occupation of empty beverage vans by males of the crab Hemigrapsus penicillatus (de Haan). Jpn. J. Ecol. 35, 377-385.

Okamoto, K. \& Kurihara, Y., 1987. Seasonal variation of population structure of Hemigrapsus penicillatus (de Haan) (Crustacea: Brachyura). Jpn. J. Ecol. 37, 81-89.

Okamoto, K. \& Kurihara, Y., 1989, Feeding habit and food selection of the grapsid crab Hemigrapsus penicillatus. Jpn. J. Ecol. 39, 195-202.

Ostenfeld, C. H., 1908. On the immigration of Biddulphia sinensis Grev. and its occurrence in the North Sea during 1903-1907. Medd. Komm. Havunders., Ser. Plankton 1, 1-46

Panning, A. \& Peters, N., 1932. Wollhandkrabbe und Elbfischerei. Hamb. Nachr. (6), 1-16.

Panning, A. \& Peters, N., 1933. Die chinesische Wollhandkrabbe (Eriocheir sinensis H. Milne-Edwards) in Deutschland. Zool. Anz. 101, (9/10), 265-271.

Peters, N., Panning, A., Thiel, H., Werner, H. \& Schmalfuß, H., 1936. Die chinesische Wollhandkrabbe in Europa. Fischmarkt (4/5), 1-19.

Pillay, K. K. \& Ono, Y., 1978. The breeding cycles of two species of grapsid crabs (Crustacea: Decapoda) from the north coast of Kyushu, Japan. Mar. Biol. 45, 237-248.

Pollard, D. A. \& Hutchings, P. A., 1990. A review of exotic marine organisms introduced to the Australian region. II. Invertebrates and algae. Asian Fish. Sci. 3, 223-250.

Pyefinch, K. A., 1950. Notes on the ecology of ship-fouling organisms. J. Anim. Ecol. 19, $29-35$.

Rawlings, T. A., 1990. Association between egg capsule morphology and predation among populations of the marine gastropod, Nucella emarginata. Biol. Bull. 179, 312-325.

Reise, K., 1993. Ausländer durch Austern im Wattenmeer. Wattenmeer Int. (3), 16-17.

Simberloff, D. Schmitz, D. C. \& Brown, T. C., 1997. Why we should care and what we should do. In: Strangers in Paradise. Impact and management of non-indigenous species in Florida. Ed. by D. Simberloff, D. C. Schmitz, \& T. C. Brown. Island Press, USA, 467 pp.

Southward, A. J. \& Crisp, D. J., 1963. Barnacles. Catalogue of marine fouling organisms (found on ships coming into European waters). Organisation for Economic Cooperation and Development (OECD) Publications, $48 \mathrm{pp}$.

Walford, L. \& Wicklund, R., 1973. Contribution to a world-wide inventory of exotic marine and anadromous organisms. FAO Fish. Tech. Pap. $121,1-49$.

Williams, M., 1996. Biological invasions. Chapman \& Hall, London, 244 pp.

Yamada, S. B. \& Boulding, E. G., 1996. The role of highly mobile crab predators in the intertidal zonation of their gastropod prey. J. Exp. Mar. Biol. Ecol. 204, 59-83. 